\title{
Good distant outcome of treatment of a patient with advanced gastric cancer
}

\section{Dobry odległy wynik leczenia chorego z zaawansowanym rakiem żołądka}

\author{
Stanisław Głuszek $k^{1,2}$, Piotr Bryk ${ }^{1}$ \\ ${ }^{1}$ Clinic of General, Oncological and Endocrine Surgery, Regional Polyclinical Hospital, Kielce, Poland \\ Head of the Clinic: Prof. Stanisław Głuszek MD, PhD \\ ${ }^{2}$ Department of Surgery and Surgical Nursing with Research Laboratory, Faculty of Health Sciences, \\ Jan Kochanowski University, Kielce, Poland \\ Head of the Department: Prof. Stanisław Głuszek MD, PhD
}

Studia Medyczne 2015; 31 (1): 52-55

DOI: $10.5114 / m s .2015 .49953$

Key words: gastric carcinomas, gastric cancer.

Słowa kluczowe: nowotwory żołądka, rak żołądka.

\begin{abstract}
The case of a patient is presented who had undergone surgical procedure of total gastrectomy, including the greater and lesser omentum, spleen, tail of the pancreas, splenic flexure of the colon, part of the diaphragm, and D2 lymphadenectomy, due to advanced gastric cancer T4bN3M0. The study covers a 9-year period of observations and check-up examinations performed on this patient. During all that time the patient remained in a good general condition, without features of cancer recurrence. Despite unfavourable prognosis in patients with clinical advancement of gastric cancer stage 3C, long-term survivals happen, such as in the case presented by the researchers. Most probably this is related with the biology of the tumour, which has not been fully recognised, and many prognostic factors of a given cancerous disease.
\end{abstract}

\section{Streszczenie}

Autorzy pracy przedstawiają przypadek pacjenta po zabiegu chirurgicznym całkowitego usunięcia żołądka z siecią mniejszą i większą, śledzioną, ogonem trzustki, zagięciem śledzionowym jelita grubego i częścią przepony oraz po limfadenektomii D2 z powodu zaawansowanego raka żołądka T4bN3M0. Praca obejmuje okres 9-letniej obserwacji i badań kontrolnych wykonywanych u tego chorego. Przez cały ten czas pacjent był w dobrym stanie ogólnym, bez cech wznowy choroby nowotworowej. Pomimo złego rokowania chorych w stopniu zaawansowania klinicznego raka żołądka IIIC, zdarzają się długoterminowe przeżycia podobnie jak w przedstawionym przez autorów przypadku. Najpewniej wiąże się to z nie do końca poznaną jeszcze biologią guza i licznymi czynnikami prognostycznymi tej choroby nowotworowej.

\section{Introduction}

Despite a decline in morbidity and mortality due to gastric cancer, which has been observed for many decades, it is still the fourth most common type of cancer and the second cause of cancer death worldwide.

In Poland, gastric cancer occupies the fifth position among males and the ninth in females, according to the frequency of occurrence. In the year 2011, 5368 people (3510 males and 1858 females) contracted malignant gastric carcinomas, which constituted 4.89\% and $2.56 \%$, respectively, of malignancies concerning all organs. In the same year, 3478 males and $1761 \mathrm{fe}$ males died from gastric cancer, the mortality rates being on the levels of $6.75 \%$ and $4.33 \%$, respectively, with relation to all malignant types of cancer. In 2011 in Poland, the mean incidence of malignant gastric carcinomas was $12 / 100,000$ in males, and 7.2/100,000 in females [1].

The most prevalent gastric cancer is adenocarcinoma, while lymphomas, gastrointestinal stromal tumours (GIST), sarcomas, and neuroendocrine tumours (NET) occur considerably more rarely [2].

The factors that exert an effect on increased risk of contracting malignant gastric cancer are: inadequate diet rich in salt, and preserved and smoked products, and a deficiency in fresh vegetables and fruits; male gender, state after partial gastrectomy; ethnic affiliation (higher incidence among the Asian population); low economic status; exposure to chemical agents; blood group A; presence of adenomatous polyps of the gastric mucosa; Helicobacter pylori infection; tobacco smoking; genetic factors; Addison-Biermer disease; and Men- 
etrier disease [3, 4]. The early stages of gastric cancer are usually asymptomatic. In the course of time, there are such symptoms as: epigastric pain, loss of weight, feeling of fullness after meal, nausea, and symptoms related to anaemia. In the advanced stages of the disease, a detectable tumour in the epigastrium may be diagnosed, ascites, and symptoms of metastases.

The best diagnostic methods remain endo-ultrasonography (EUS) and gastroscopy, which enable the collection of specimens for histopathological testing in order to make a diagnosis [5].

Early stages of gastric cancer T1aN0 and infiltration $<2 \mathrm{~cm}$ may be treated by endoscopic methods, in the case of tumours $\leq \mathrm{T} 1 \mathrm{bN} 0-1 \mathrm{M} 0$ the scope of surgery may be limited to partial gastrectomy and D1+ lymphadenectomy. In all other stages of advancement, total gastrectomy or the removal of at least $2 / 3$ of the stomach is recommended (according to the site of tumour) with D2 lymphadenectomy. When infiltration of adjacent organs is diagnosed, resections are justifiable expanded by the excision of the affected organs. In patients with distant metastases in good condition, chemotherapy treatment $(\mathrm{CTH})$ or palliative surgery are recommended, while in patients whose general condition is poor exclusively symptomatic treatment is recommended.

The objective of the study was the presentation of distant outcomes of treatment of a patient who had undergone the surgical procedure of total gastrectomy, including the greater and lesser omentum, spleen, tail of the pancreas, splenic flexure of the colon, part of the diaphragm, and D2 lymphadenectomy, due to advanced gastric cancer T4bN3M0. The study covers a 9-year period of observations and check-up examinations performed on this patient.

\section{Case report}

The 51-year-old patient was admitted to the Surgical Ward on 15 August 2005 for elective surgical procedure due to gastric cancer. In the medical history he had complained for 3-4 months of pain in the epigastrium, accompanied by loss of appetite and loss of weight by approx. $20 \mathrm{~kg}$. On 16 August 2005, the patient underwent surgery of total gastrectomy, including the greater and lesser omentum, spleen, tail of the pancreas, splenic flexure of the colon, part of the diaphragm, and D2 lymphadenectomy (Figure 1); oesophageal intestinal anastomosis was performed end-to-side with Braun's jejunostomy, colon end-toend anastomosis, the diaphragm was sutured, and two drains inserted - into the peritoneal cavity and the left pleural cavity.

Individual specimens were sent for histopathological examination, and the following results were obtained:

- Stomach of length of $24 \mathrm{~cm}$ with arising ulcerated tumour at the fundus and subcardially, of size
$16 \times 12 \mathrm{~cm}$, infiltrating per continuationem the adjacent spleen. The adjacent fragment of the tail of the pancreas probably focally infiltrated by the tumour. The adjacent fragment of the transverse colon affected by tumour infiltration. The margin of the gastric cardia approx. $2 \mathrm{~cm}$, further margin approx. $10 \mathrm{~cm}$ Adenocarcinoma tubulare ventriculi G3. Metastases carcinomatosis in lymphonodulis 7/28. pT4N2. Poorly differentiated adenocarcinoma with stromal fibrosis and inflammatory infiltrations. Infiltration of the full thickness of the gastric wall and per continuationem - the spleen, the full thickness of the colon and the peritoneum of the diaphragm, without infiltration of muscle fibres. Metastases of the cancer found in peripancreatic lymph nodes (2/3), and subcardial lymph nodes (5/10). Lymph nodes along the lesser curvature of the stomach (0/7) and greater curvature $(0 / 8)$ without metastasis of the cancer. Surgical margins proximal and distal, as well as radial, within the infiltrated organs free from cancerous pattern. The omentum without infiltrations of cancer.

- Lymph nodes group 12 - Lymphadenitis chronica $0 / 2$.

- Lymph nodes group 8 - Lymphadenitis chronica $0 / 3$.

- Specimen from the left hepatic lobe - hyalinized tumour without cancerous infiltration.

- Both fragments of the diaphragm - both fragments without infiltration of cancer.

- In check-up laboratory and imaging examinations the following were found:

- Blood count: HCT - 33.8\%; HGB - 12.1 g\%; RBC $4.70 \mathrm{M} / \mu \mathrm{l} ; \mathrm{WBC}-15.5 \mathrm{~K} / \mu \mathrm{l} ; \mathrm{PLT}-631 \mathrm{~K} / \mu \mathrm{l}$.

- Biochemistry: glucose - 102 mg\%; AspAT - $31 \mathrm{U} / \mathrm{l}$; AlAT - $23 \mathrm{U} / \mathrm{l}$; amylase - $31 \mathrm{U} / \mathrm{l}$; urea - 25 mg\%; creatinine - $0.73 \mathrm{mg} \%$; bilirubin - $1.99 \mathrm{mg} \%$; $\mathrm{Ca}^{2+}$ $3.9 \mathrm{mEq} / \mathrm{l}$; Phos $-8.3 \mathrm{mg} \%$.

- Lipidogram: Chol - 79 mg\%; LDL - 27 mg\%; HDL 13 mg\%; TG - 197 mg\%.

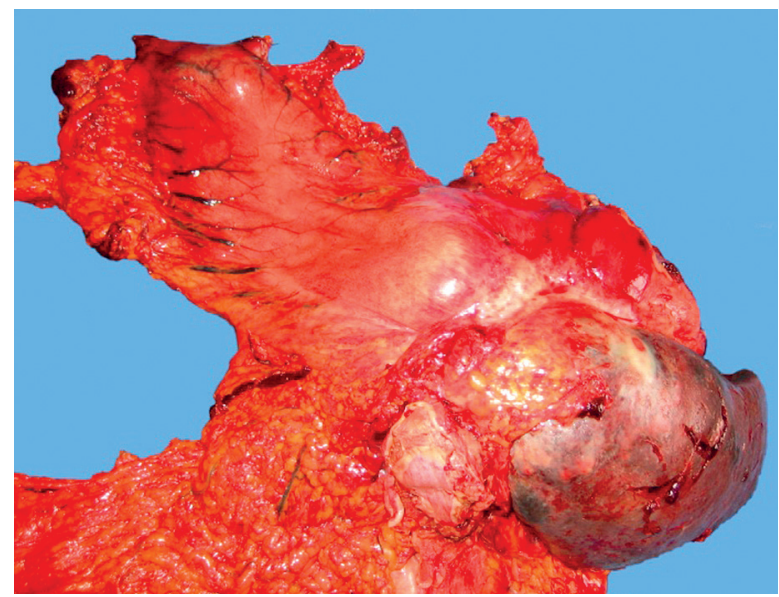

Figure 1. Gastric cancer infiltrating adjacent organs 
- Coagulation system: PT - 15.8"; WSK - 90.5\%; INR - 1.1; APPT - 30.5"; TT - 16.0".

- Proteinogram: total protein - $4.4 \mathrm{~g} / \mathrm{dl}$; albumins $46.1 \%$.

- Cancer markers: CEA - 3.14 ng/ml; Ca19-9 - 6.92 U/ $\mathrm{ml}$.

- Abdominal ultrasound: The liver with two hyperechoic areas with diameters $27 \mathrm{~mm}$ and $19 \mathrm{~mm}$ within the right lobe next to the vessel. The gall bladder with condensed bile in its lumen, without deposits. The kidneys without features of urinary retention and cholelithiasis. A trace of fluid in the Morison's pouch, perisplenically and in the interloop subphrenic-rectal recess. Traces of fluid in the left pleural cavity. Clear accumulations of fluid in the abdominal cavity were not observed. The pancreas and retroperitoneal space were not available for examination - flatulence.

- Chest radiograph: Residual pulmonary oedema in the left apex of the lung. Fluid in the left pleural cavity reaching rib 8 at the axillary line. Fibrosis in the middle area of the left lung. Apart from this, the lungs and heart were appropriate to the age of the patient.

The state of the patient after surgery - stable. Course of hospitalisation was without complications. On day 13 after surgery, the patient was discharged home in a relatively good condition.

Subsequently, during the period 2005-2013, the patient was subjected to a 9-year observation with annual health check-ups. For this entire period he felt well and did not report any complaints. No weight loss was noted. In laboratory tests, including blood count, biochemical tests, ionogram, and coagulology, no deviations were found. The level of tumour markers CEA and Ca19-9 remained normal. In the imaging tests performed, i.e. chest radiograph, abdominal ultrasound, and computed tomography (CT), and gastroscopic examination no features of cancer recurrence were observed.

On 9 October 2014, the patient reported to the hospital due to dizziness and pain complaints concerning the head, with accompanying weight loss. Comprehensive imaging diagnostics were performed (CT of the head, CT scan of the chest, CT of abdominal cavity, gastroscopy), and the left lung tumour was diagnosed with metastases into the CNS. The results of histopathological examination of the specimen of the above-mentioned tumour confirmed pulmonary adenocarcinoma G3. The patient was referred to the Department of Radiotherapy at the Kielce Region Oncology Centre for further treatment.

\section{Discussion}

The presented case dealt with a patient suffering from gastric cancer T4bN3M0 (acc. to THM Classification, $7^{\text {th }}$ Edition of 2010) spreading through the serous membrane and infiltrating the adjacent organs. Histopathological examination confirmed that 7 lymph nodes were affected. No distant metastases were diagnosed. Based on the TNM classification, the stage of clinical advancement was determined to be 3C. According to the American Cancer Society the outcomes of 5-year survival of a patient with gastric cancer at this stage of advancement are on the level of $4 \%$.

The most important prognostic factor in patients with gastric cancer is the stage of clinical advancement determined by the depth of tumour infiltration, involvement of the lymph nodes, and the presence of distant metastases. However, in patients with gastric cancer at the same stage of the TNM Classification there are differences in survival. Therefore, attention should be paid to other pathological features of the tumour, on which the prognosis depends $[6,7]$. These features include, originating from the genetic processes, biological prognostic factors such as: expression of epithelial growth factor receptor (EGFR) and human epidermal growth factor receptor 2 (HER2), DNA copy number changes, microsatellite instability, changes in expression of a number of factors including timidilane synthase, $\beta$-catenin, mucin antigen, protein p53, inhibitors of COX-2, matrix metalloproteinase, and vascular endothelial growth factor (VEGF) [8, 9]. From the above-mentioned feratures, EGFR over-expression was detected in $60 \%$, and HER 2 in $15-20 \%$ of cases of gastric cancer [10-13], whereas expression of induced nitric oxide synthase (iNOS) occurred in $85 \%$, and VEGF in $92 \%$ of cases of advanced gastric cancer [14].

In the study of 23 July 2014, researchers from the Cancer Genome Atlas divided gastric adenocarcinoma into 4 subtypes according to molecular characterisation. Tumours in the first subgroup, which constituted 9\%, were positive against Epstein-Barr virus (EBV). Tumours in the second subgroup (22\%) were characterised by high microsatellite instability (MSI). The remaining subgroups differed with respect to the number and frequency of chromosomal aberrations. Tumours in the third subgroup, which constituted $20 \%$, were considered as having a low level of aberrations and were named genome stable (GS). The remaining $50 \%$ of tumours were classified as chromosomally unstable, with a high level of aberrations (CIN) [15].

EBV-positive carcinomas showed a high frequency of mutations in the PIK3CA gene encoding protein component PI3-kinase, indispensable for cell growth and division. The researchers suggest that EBV-positive carcinomas may respond to PI3-kinase inhibitors, some of which are in the early stages of clinical trials. Some carcinomas in the EBV-positive subgroup also showed larger gene copy numbers produced in the chromosomal region containing the JAK2 gene. The JAK2 protein facilitates cell growth and division, and, in addition, an increase in JAK2 expression may inappropriately activate cell growth. The strengthened 
area also contains genes for two proteins: PD-PD-L1 and $\mathrm{L} 2$, which inhibit immune response. Hence, the subsequent suggestion that JAK2 and PD-L1/2 inhibitors may be useful in the treatment of EBV-positive gastric carcinomas. Another characteristic of the above-mentioned group of adenocarcinomas is DNA hypermethylation, resulting in reduced gene expression. The subsequent subgroup $(22 \%)$ comprised tumours characterised by microsatellite instability (MSI), which showed an increased number of mutations, including mutations in the gene encoding proteins signalling oncogenic processes. Genome stable tumours (GS) contained a mutation of the RhoA gene, the product of which acts with other cellular proteins in order to change the shape of the cell and its migration, which is important in the development of cancer. The remaining subgroup comprised chromosomally unstable tumours (CIN), which are characterised by aneuploidy with a focal increase in tyrosine kinase receptors.

While analysing the above-mentioned molecular subgroups of adenocarcinoma from the clinical and histologic aspects, it was found that one of the types of histo-clinical classification according to Lauren diffuse cancer - occurred in the subgroup of genomestable tumours (GS). In addition, it was observed that the majority of gastroesophageal junction carcinomas were within the groups of cancers CIN (65\%), while EBV tumours were present in the gastric body and gastric fundus $(62 \%)$, and more frequently occurred among males (81\%). The GS tumours were generally diagnosed at a younger age (median 59 years), while the MSI tumours, at a relatively older age (median $>72$ years) and in females (56\%). The researchers did not observe any statistically significant differences in the frequency of occurrence of any of the subtypes according to race, length of survival period, and type of subgroup [15]. It is difficult to precisely characterise the described case according to the above-presented division. It may belong to the group of tumours CIN - of the gastroesophageal junction as diffuse cancer, according to Lauren, or a mixed type. Despite infiltration of adjacent organs and many metastases to the lymph nodes, it was possible to achieve long survival.

This classification may serve as a valuable addition to the histopathological examination, constituting a source of further development of clinical studies aimed at determination of the best possible therapy for an individual group of patients.

\section{Conclusions}

The presented case of a patient with gastric cancer with the highest stage of clinical advancement and very unfavourable diagnosis illustrates distant outcomes of treatment without features of recurrence, which is undoubtedly due to the biology of the cancer tumour, which has not been finally recognised.

\section{Conflict of interest}

The authors declare no conflict of interest.

\section{References}

1. Krajowy Rejestr Nowotworów.

2. Potemski P, Polkowski W. Zalecenia postepowania diagnostyczno-terapeutycznego w nowotworach złośliwych. Via Medica 2013; 125-35.

3. Buas MF, Vaughan TL. Epidemiology and risk factors for gastroesophageal junction tumors: understanding the rising incidence of this disease. Semin Radiat Oncol 2013; 23: 3-9.

4. Piazuelo BM, Correa P. Gastric cancer: overview. Colomb Med 2013; 44: 192-201.

5. Olszewska M, Głuszek S. New possibilities for the treatment of gastric cancer. Studia Medyczne 2013; 29: 343-8.

6. Park D, Yun JW, Park JH, et al. HER-2/neu amplification is an independent prognostic factor in gastric cancer. Dig Dis Sci 2006; 51: 1371-9.

7. Bilici A. Treatment options in patients with metastatic gastric cancer: current status and future perspectives. World J Gastroenterol 2014; 20: 3905-15.

8. Li LF, Wei ZJ, Sun H, et al. Abnormal beta-catenin immunohistochemical expression as a prognostic factor in gastric cancer: a meta-analysis. World J Gastroenterol 2014; 20: $12313-21$.

9. Scartozzi M, Galizia E, Freddari F, et al. Molecular biology of sporadic gastric cancer: prognostic indicators and novel therapeutic approaches. Cancer Treat Rev 2004; 30: 451-9.

10. Jørgensen JT. Role of human epidermal growth factor receptor 2 in gastric cancer: biological and pharmacological aspects. World J Gastroenterol 2014; 20: 4526-35.

11. Jørgensen JT, Hersom M. HER2 as a prognostic marker in gastric cancer - a systematic analysis of data from the literature. J Cancer 2012; 3: 137-44.

12. Ku GY, Ilson DH. Esophagogastric cancer: targeted agent. Cancer Treat Rev 2010; 36: 235-48.

13. Wagner AD, Moehler M. Development of targeted therapies in advanced gastric cancer: promising exploratory steps in a new era. Curr Opin Oncol 2009; 21: 381-5.

14. Song ZJ, Gong P, Wu YE. Relationship between the expression of iNOS, VEGF, tumor angiogenesis and gastric cancer. World J Gastroenterol 2002; 8: 591-5.

15. Cancer Genome Atlas Research Network: Comprehensive molecular characterization of gastric adenocarcinoma. Nature 2014; 513: 202-9.

\section{Address for correspondence:}

Piotr Bryk MD

Clinic of General, Oncological and Endocrine Surgery Regional Polyclinical Hospital

ul. Grunwaldzka 45, 25-736 Kielce, Poland

Phone: +4841367 1571

E-mail: bryk.piotr@gmail.com 